six at Wairoa. The greatest felt, reckoned on the modified Mercalli scale, was on January 24, about Foveaux Strait, where the intensity reached scale V. Greater instrumental magnitudes occurred on January 4 and January 9, though the former only attained modified Mercalli scale III at Ohakune and Taihape, and the latter, from an epicentre some $200 \mathrm{~km}$. distant, was apparently not felt in New Zealand.

\section{Earthquakes Registered in Spain}

DurING the month of March 1943, thirty earthquakes were registered by the seismographs at the Observatory at Toledo (Registro de las observaciones provisionales correspondientes al mes de Marzo de 1943, Observatorio Geofisico de Toledo). Twelve of these were sufficiently strong and well registered as to have their epicentral distances determined, and two further shocks had their epicentral distances provisionally determined. The largest shock of the month to be recorded was on March 9. This began with $e P z$ at $10 \mathrm{~h} .02 \mathrm{~m}$. 59s. from an epicentre some $11,180 \mathrm{~km}$. distant and attained a maximum ground amplitude at Toledo of $74 \mu$ at $10 \mathrm{~h} .45 \mathrm{~m}$. $47 \mathrm{~s}$. The second strongest shock of the month to be recorded was on March 21, which began with $i P z$ at $20 \mathrm{~h}$. $55 \mathrm{~m} .09 \mathrm{~s}$. and attained a maximum amplitude of $29 \mu$ at $21 \mathrm{~h} .56 \mathrm{~m} .23 \mathrm{~s}$. The epicentre was $16,000 \mathrm{~km}$. from Toledo. Two shocks, apparently from the same epicentre $9,500 \mathrm{~km}$. from Toledo, had a depth of focus of approximately $120 \mathrm{~km}$. These were on March 14 and 15. The only 'near' earthquake of the month was apparently on March 26. The epicentre was $560 \mathrm{~km}$. from Toledo and the focus was $25 \mathrm{~km}$. deep, but as the azimuth was not determined, other observations are required before the epicentre can be accurately determined.

\section{Invention of the Barometer}

THE tercentenary of the invention of the barometer will be marked by a meeting, to be held at the University of Toronto on October 19, arranged by a committee including representatives of the Royal Meteorological Society (Canadian Branch), Royal Astronomical Society of Canada, Royal Canadian Institute and the University of Toronto. Papers will be presented by Prof. L. C. Karpinski on "Telescope, Microscope, and Barometer as a Point of Departure for the Natural Sciences"; Prof. G. S. Brett on "The Effects of the Discovery of the Barometer on Contemporary Thought" ; W. E. Knowles Middleton on "Subsequent History of the Barometer" ; and Prof. John Satterly on "The Applications of the Barometer in Physics and Chemistry". Correspondence should be addressed to the secretary of the Committee, A. D. Thiessen, 315 Bloor Street West, Toronto, Canada.

\section{Epidemiology of Leprosy}

Accordrng to a paper on this subject by Dr. G. W. McCoy, medical director (retired) of the United States Public Health Sérvice (Public Health Rep., Dec. 18), leprosy tends to disappear from many parts of the world, while in other parts it tends to spread freely. At the present time in Europe the disease spreads apparently only in the countries bordering on the Mediterranean and the Baltic. As regards the United States, in Louisiana, Florida and Texas the presence of imported cases from the British West Indies, Dutch Guiana, South America, China and Chile, has resulted in the establishment of foci in which the disease shows a strong tendency to perpetuate itself, while in the central north-western States, such as Minnesota, leprosy has shown little tendency to become established. In other parts of the United States the disease is so rare as to be practically negligible from the public health aspect. Dr. McCoy concludes that in an age in which great social and economic changes are occurring, it is impossible to predict what effect they may have on leprosy or other diseases.

\section{Deaths from Exposure to Cold}

According to an editorial in the January issue of the Statistical Bulletin of New York, during the eightyear period for which data are available, namely, 1933-41, the deaths in the United States from exposure to excessive cold-freezing, frostbite, etc.were on the average 363 annually or about 3 per $1,000,000$ persons. The highest figure (579) was reached in 1936 when there was exceptionally cold weather over a large part of the country, while the minimum figure of 190 in the period was in 1939 . In the United States as a whole, males were the victims of exposure to excessive cold about four times as frequently as females, and two thirds of the male deaths occurred in men of fifty and more, many of whom were probably suffering from arterial diseases and therefore more susceptible to the effects of exposure. The highest rates in the country were found in the mountain States of Nevada, Montana, and Wyoming, while the district of Columbia was lowest and California came next.

\section{Announcements}

DR. W. G. OGG, director of the Macaulay Institute for Soil Research, Aberdeen, has been appointed to succeed Sir John Russell as director of the Rothamsted Experimental Station on Sir John Russell's retirement at the end of September.

Str Lawrence BragG, Cavendish professor of experimental physics in the University of Cambridge, and Prof. C. G. Douglas, professor of general metabolism in the University of Oxford, have joined the Council of the Gas Research Board.

DR. E. W. Smirh, president-elect of the Institute of Fuel, has been awarded the Birmingham medal of the Institution of Gas Engineers, in acknowledgment of his outstanding work during the past thirty years for the gas industry. The Birmingham medal was founded some sixty years ago, and has only been presented on fourteen previous occasions during that period.

Mr. R. W. Paul, who died on March 28 (see Nature, April 24, p. 470), has left the proceeds from the sale of his shares in Cambridge Instrument Company (to be called the R. W. Paul Instrument Fund) to be used for the design, construction and maintenance of novel or unusual instruments for investigation in physical science, and subject thereto to the Royal Institution, the Physical Society and the Royal Society; and on his wife's decease $£ 5,000$ to the research fund of the Royal Institution of Great Britain, and $£ 500$ each to the Benevolent Fund of the Institute of Physics, the Cinematograph Trade Benevolent Fund, and the Benevolent Fund of the Institution of Electrical Engineers. 